\title{
Caregiving in
}

Alzheimer's and

Other Dementias 


\section{YALE UNIVERSITY PRESS HEALTH \& WELLNESS}

A Yale University Press Health \& Wellness book is an authoritative, accessible source of information on a health-related topic. It may provide guidance to help you lead a healthy life, examine your treatment options for a specific condition or disease, situate a healthcare issue in the context of your life as a whole, or address questions or concerns that linger after visits to your healthcare provider.

For a complete list of titles in this series, please consult yalebooks.com.

Joseph A. Abboud, M.D., and Soo Kim Abboud, M.D., No More Joint Pain

Thomas E. Brown, Ph.D., Attention Deficit Disorder: The Unfocused Mind in Children and Adults

Patrick Conlon, The Essential Hospital Handbook: How to Be an Effective Partner in a Loved One's Care

Richard C. Frank, M.D., Fighting Cancer with Knowledge and Hope:

A Guide for Patients, Families, and Health Care Providers

Michelle A. Gourdine, M.D., Reclaiming Our Health: A Guide to African American Wellness

Marjorie Greenfield, M.D., The Working Woman's Pregnancy Book

Ruth H. Grobstein, M.D., Ph.D., The Breast Cancer Book:

What You Need to Know to Make Informed Decisions

James W. Hicks, M.D., Fifty Signs of Mental Illness:

A Guide to Understanding Mental Health

Steven L. Maskin, M.D., Reversing Dry Eye Syndrome:

Practical Ways to Improve Your Comfort, Vision, and Appearance

Mary Jane Minkin, M.D., and Carol V. Wright, Ph.D., A Woman's Guide to Menopause and Perimenopause

Arthur W. Perry, M.D., F.A.C.S., Straight Talk about Cosmetic Surgery

Eric Pfeiffer, M.D., Caregiving in Alzheimer's and Other Dementias

Eric Pfeiffer, M.D., Winning Strategies for Successful Aging

Madhuri Reddy, M.D., M.Sc., and Rebecca Cottrill, R.N., M.Sc.C.H. Healing Wounds, Healthy Skin:

A Practical Guide for Patients with Chronic Wounds

E. Fuller Torrey, M.D., Surviving Prostate Cancer:

What You Need to Know to Make Informed Decisions 


\section{Caregiving in}

Alzheimer's and Other Dementias

\section{Eric Pfeiffer, M.D.}

FOREWORD BY

Gayle Sierens

Yale UNIVERSITY PRESS

New Haven \& London 
The information and suggestions contained in this book are not intended to replace the services of your physician or caregiver. Because each person and each medical situation is unique, you should consult your own physician to get answers to your personal questions, to evaluate any symptoms you may have, or to receive suggestions for appropriate medications.

The author has attempted to make this book as accurate and up to date as possible, but it may nevertheless contain errors, omissions, or material that is out of date at the time you read it. Neither the author nor the publisher has any legal responsibility or liability for errors, omissions, out-of-date material, or the reader's application of the medical information or advice contained in this book.

Copyright (c) 2015 by Eric Pfeiffer, M.D.

All rights reserved.

This book may not be reproduced, in whole or in part, including illustrations, in any form (beyond that copying permitted by Sections 107 and 108 of the U.S. Copyright Law and except by reviewers for the public press), without written permission from the publishers.

Yale University Press books may be purchased in quantity for educational, business, or promotional use. For information, please e-mail sales.press@yale.edu (U.S. office) or sales@yaleup.co.uk (U.K. office).

Designed by James J. Johnson.

Set in Swift type by Integrated Publishing Solutions.

Printed in the United States of America.

Library of Congress Cataloging-in-Publication Data

Pfeiffer, Eric, 1935-

Caregiving in alzheimer's and other dementias / Eric Pfeiffer, M.D. ; foreword by Gayle Sierens, News Anchor, NBC-TV, Tampa, Florida.

pages $\mathrm{cm}$

Includes index.

ISBN 978-0-300-20798-9 (pbk. : alk. paper) 1. Alzheimer's disease-Patients-

Care. 2. Caregivers. I. Title.

RC523.P436 2015

616.8'31-dc23

2014033323

A catalogue record for this book is available from the British Library.

This paper meets the requirements of ANSI/NISO Z39.48-1992

(Permanence of Paper).

$\begin{array}{llllllllll}10 & 9 & 8 & 7 & 6 & 5 & 4 & 3 & 2 & 1\end{array}$ 